T. А. Бороноева. Национальный музей Республики Бурятия как ресурс региональной креативной экономики

Научная статья

УДК 33 (571.14)

DOI 10.18101/2304-4446-2021-3-19-26

\title{
НАЦИОНАЛЬНЫЙ МУЗЕЙ РЕСПУБЛИКИ БУРЯТИЯ КАК РЕСУРС РЕГИОНАЛЬНОЙ КРЕАТИВНОЙ ЭКОНОМИКИ
}

\author{
(C) Бороноева Татьяна Анатольевна \\ кандидат искусствоведения, \\ директор, Национальный музей Республики Бурятия \\ Россия, 670000, г. Улан-Удэ, ул. Куйбышева, 29 \\ tatboronoeva@gmail.com
}

\begin{abstract}
Аннотация. В статье изучена роль Национального музея Республики Бурятия в развитии региональной креативной экономики. Музей в своих фондах хранит уникальное культурное наследие, которое считается одним из основных ресурсов креативной экономики. На протяжении последних десяти лет музей активно занимается разработкой фирменного знака в издательской и сувенирной продукции, продвижением собственной линейки музейного продукта, созданной на основе богатейших коллекций, организацией инфраструктуры сбыта (на площадке Художественного музея открыта выставка-продажа «Арт-Бэлиг»). Также рассмотрена деятельность музея в рамках концепции «экономика впечатлений» - как значимого участника в брендировании территории, расширения культурного туризма и творческих индустрий. Таким образом, в статье отмечается, что Национальный музей Республики Бурятия может считаться полноправным участником региональных культурных индустрий.
\end{abstract}

Ключевые слова: музей; креативная экономика; ресурс; культура; наследие; музейный продукт; туризм; коллекция; выставка

\section{Для цитирования}

Бороноева Т. А. Национальный музей Республики Бурятия как ресурс региональной креативной экономики // Вестник Бурятского государственного университета. Экономика и менеджмент. 2021. № 3. С. 19-26.

2021 г. объявлен ООН Международным годом креативной экономики. Креативная экономика - особый сектор экономики, объединяющий виды деятельности, связанные с интеллектуальной работой, креативностью и творчеством. Креативная экономика обширна и ее участники разнообразны. В центре этой динамичной экономики находятся культурная и креативная индустрии, расположенные на стыке культуры, искусства, бизнеса, товарооборота и инновационных технологических разработок [5].

В 2010 г. Конференция ООН по торговле и развитию (ЮНКТАД) и Программа развития ООН (ПРООН) совместно представили доклад «Креативная экономика - отчет за 2010 г.», в котором были выделены отрасли креативной экономики [1, с. 23-58].

В докладе данные индустрии разделены на четыре группы. Согласно разделению музеи относятся к первой группе - культурное наследие, которое выступает источником всех форм искусства, культурных и креативных индустрий. Наследие несет в себе культурные аспекты исторического, антропологического, 
этнического, эстетического и социального развития каждой страны. Эта группа разделена на две подгруппы:

- отрасли, выражающие традиционную культуру: художественные ремесла, фестивали и праздники;

- культурные достопримечательности: культурные и исторические памятники, места раскопок, музеи, библиотеки, выставки и т. д. [1, с. 23-58].

Первоначально деятельность музеев и их коллекции как культурное наследие в большей степени относили к ресурсам креативной экономики, так как музеи не являются в полной мере коммерческими предприятиями [10].

За последние годы нужно отметить, что музеи быстро развиваются от простой демонстрации древностей в учреждения с более клиенториентированным направлением деятельности.

Сегодня значительно возросла роль региональных музеев как значимых участников брендирования территории, расширения культурного туризма и творческих индустрий. Одним из ярких примеров может стать деятельность Национального музея Республики Бурятия, который в этом году отмечает свое десятилетие.

В 2011 г. музей был образован путем объединения четырех ведущих региональных музеев - Музея истории Бурятии им. М. Н. Хангалова, Республиканского художественного музея им. Ц. С. Сампилова, Музея природы Бурятии и Новоселенгинского музея декабристов. Музей хранит в своих фондах около 155000 уникальных артефактов, раскрывающих историю, культуру и традиции региона.

За 10 лет своей деятельности Национальный музей Республики Бурятия стал одним из ведущих музеев, известным далеко за пределами республики. Благодаря поддержке Министерства культуры Российской Федерации, Правительства Республики Бурятия он проводит масштабные выставочные проекты, осуществляет на различных площадках трансляцию региональной идентичности, успешно ведет работу в сфере социокультурного проектирования, образовательной деятельности и т. д.

С первых дней работы музей выбрал новый вектор развития, направленный на внедрение инновационных технологий в музейную деятельность — экспозиционно-выставочную, учетно-хранительскую, расширение информационной доступности, изменение сервиса обслуживания посетителей. Одним из важных аспектов экономической составляющей деятельности музеев является их инновационное развитие.

Руководством музея была продумана стратегия маркетинговой политики, музейного менеджмента, выделены сектор по продвижению и связям с общественностью и экономический сектор.

В 2011 г. был разработан единый музейный логотип, объединяющий четыре центра музея. Музейный логотип активно использовался как фирменный знак в издательской и сувенирной продукции. В 2020 г. был создан ребрендинг музейного логотипа, который символизирует все центры и новое здание музея в виде цветка ая-ганга с четырьмя лепестками.

На протяжении 10 лет музей ведет свой сайт, проводит активную работу на официальных страницах во всех популярных социальных сетях: Facebook, 
T. А. Бороноева. Национальный музей Республики Бурятия как ресурс региональной креативной экономики

Instagram, ВКонтакте, Одноклассники, You tube, Яндекс. Сегодня в этих социальных сетях у музея около 22000 виртуальных посетителей. В 2021 г. сайт музея был обновлен, добавлена функция онлайн-покупки билета на выставки, лекции, интерактивные занятия, мастер-классы.

Музеем за последние годы была проделана большая работа по созданию различных проектов с использованием современных интерактивных технологий: ЗД-панорамы выставок, предоставление данных с использованием информационной мультимедиасенсорных киосков, тачскринов, экранов, создание QR-кодов к постоянным экспозициям музея как вариант электронного этикетажа на основе использования смартфонов.

В 2015 г. музей открыл виртуальное представительство Государственного музея истории религии (г. Санкт-Петербург) с информационно-образовательным ресурсом «Буддизм на берегах Невы» [4, с. 96].

24 сентября 2019 г. в Художественном центре им. Ц. С. Сампилова открылся информационно-образовательный центр «Русский музей: виртуальный филиал». Сегодня, благодаря цифровой коллекции Русского музея музей стал базой ведения научно-исследовательской деятельности для искусствоведов, историков искусства, учащихся школ искусств, студентов вузов, СУЗов по русскому искусству. Также центр рассчитан на методическую работу с профессиональной музейной аудиторией региона для ознакомления с новыми видами деятельности в виде виртуальных экспозиций с внедрением мультимедийных, VR, IT-технологий.

Национальный музей Бурятии в 2019 г. стал участником Национального проекта «Культура» в программе по созданию мультимедиагидов по музеям России с применением технологии дополненной реальности «ARTEFACT».

В 2019-2020 гг. сотрудниками музея совместно с разработчиками платформы были созданы мультимедийные гиды по выставке «Атлас тибетской медицины», постоянным экспозициям Художественного музея - «Русское искусство XVIII - начала XX в.» и Музея природы Бурятии - «Таёжная, озерная, степная».

В 2020 г. Национальный музей благодаря грантовой поддержке подготовил два виртуальных проекта. Одним из них стал лонгрид - виртуальный каталог выставки «Допетровская Русь в Бурятии», посвященный истории старообрядцев Забайкалья. В виртуальном формате лонгрида представлены уникальные иконы, религиозные книги и самобытные народные костюмы, видео, аудио, комментарии аутентичных носителей многовековой культуры - семейских (старообрядцев), признанной ЮНЕСКО шедевром нематериального наследия человечества (2001). Следующим проектом стал электронный каталог «Лики Гэсэриады», который впервые представил широкой аудитории пользователей интернета уникальную коллекцию более 200 произведений изобразительной «Гэсэриады» из фондов графики Национального музея.

В 2020 г. был подготовлен грант благотворительного фонда Алишера Усманова «Искусство, наука и спорт» в рамках программы поддержки людей с нарушением зрения «Особый взгляд» на создание 5 тактильных моделей уникальных картин из коллекции музея: «Девушки с ведрами» А. Н. Сахаровской, «Сбивание масла» Л. Д. Доржиева, «Тайлаган» Р. С. Мэрдыгеева, «Арканщик» Ц. С. Сампилова и «Ной проклинает Хама» И. С. Ксенофонтова. Тактильные модели картин 
представлены на постоянных экспозициях: «Русское искусство конца XVIII начала XX в.» и «Тактильная юрта».

В 2020 г. также на уличной территории музея создана интерактивная площадка «Музейный дворик», представляющая собой образовательный комплекс адаптированная для людей с ограниченными возможностями здоровья. Имеется пандус для заезда маломобильных граждан на территорию «Музейного дворика». Одна из зон площадки - это тактильная дорожка, состоящая из материалов, разнообразных по форме и текстуре. Интерактив - песочница «Палеонтологические раскопки», карта животного и растительного мира Бурятии, грифельная доска для рисования по высоте и форме сконструированы таким образом, чтобы быть доступными для всех категорий посетителей. Имеется искусственный пруд, имитирующий водный ландшафт республики, что позволяет, находясь в городской среде, прикоснуться к дикой природе. Для удобства посетителей площадка оснащена скамейками для отдыха.

Внедрение интерактивных форм работы, новых технологий, грамотно встроенных в музейное пространство, придает привлекательность имиджу музея, добавляют досуговую составляющую, повышают экспозиционную активность посетителя и спрос на музейные услуги.

В 2012 г. Национальный музей Бурятия открыл выставку-продажу современного бурятского изобразительного искусства «Арт-Бэлиг». Это был первый опыт развития профессионального художественного рынка на площадке музея. Основной задачей проекта «Арт-Бэлиг» было предоставление возможности региональным художникам показать свои работы широкой публике. Выставка стала местом диалога творца и зрителя - потенциального покупателя при участии профессиональных кураторов, искусствоведов и музейных сотрудников.

В настоящее время на выставке экспонируются работы около 120 авторов, это более чем 500 изделий. Это живописные и графические работы, скульптура, мелкая пластика, резьба, ювелирные украшения, посуда, авторские изделия, литературная и сувенирная продукция и т. д. Реэкспозиция выставки происходит постоянно. За последние годы выставка-продажа «Арт-Бэлиг» стала известна далеко за пределами республики и является важной частью в логистике культурного туризма региона [2, с. 7-13].

С первых же дней открытия выставки «Арт-Бэлиг» музей активно начал работать в сфере реализации собственного ассортимента музейного продукта. С 2012 г. выпускались ежегодные календари с музейными экспонатами, наборы открыток с уникальными объектами культуры на русском и английском языках, сувенирная продукция с использованием фирменного знака, элементов фирменного стиля - различные цветовые вариации логотипа, шрифты и т. д.

С 2019 г. музей начал выпускать серии тканевых сувениров: сумки, косметички, подушки, гобелены, платки и другие. Музейные сувениры-принты изготовлены по мотивам произведений выдающихся художников Бурятии, уникальных буддийских, этнографических и археологических экспонатов из коллекции Национального музея Бурятии.

В марте 2021 г. была разработана и заказана новая линейка сувениров - декоративная керамическая тарелка с рисунками А. О. Цыбиковой «Фрагмент реки Селенги» и Ю. Е. Мандаганова «Принцесса». 
T. А. Бороноева. Национальный музей Республики Бурятия как ресурс региональной креативной экономики

В мае 2021 г. к международному музейному фестивалю «Дни Эрмитажа в Улан-Удэ», посвященному празднованию 100-летия Республики Бурятия, была проведена большая работа по подготовке брендированной сувенирной продукции: папки, блокноты, ручки, календари, магнитные закладки, каталог, шоколад и т. д.

Таким образом, музей, храня уникальное культурное наследие, имея огромный потенциал для разработки и продвижения музейного товара, логистику сбыта (выставка - продажа «Арт-Бэлиг», музейные киоски во всех центрах), в настоящее время становится полноценным участником республиканских креативных индустрий.

Следует учитывать, что эффект измеряется не только прямым или опосредованным вкладом в экономику, даже экономистами признается еще и так называемый «неизмеримый» социальный эффект - это изменение качества жизни, формирование культурной идентичности, развитие плюрализма и толерантной атмосферы в обществе. И если музеи по экономическим показателям существенно проигрывают, то по «незримому» эффекту они составляют реальную конкуренцию ведущим видам деятельности культурных индустрий [9, с. 28].

За десять лет работы музеем были организованы масштабные выставочные проекты, которые отличались как креативным подходом к созданию экспозиции, так различными коллаборациями с другими организациями, учреждениями культуры и т. д.

В 2013 г. Национальный музей Республики Бурятия в рамках указа Президента Российской Федерации от 7 мая 2012 г. № 597 «О мероприятиях по реализации государственной социальной политики» открыл масштабную выставку «От Петра до Павла. Художественные сокровища императорской России XVIII века» Музеев Московского Кремля. Музей провел огромную работу по высокой организации выставочного проекта, тем самым доказав осуществимость крупных проектов и для музея вырос масштаб денежных вложений в экспозиционновыставочную деятельность. За два месяца работы выставку посетили 12000 жителей и гостей Бурятии $[4$, c. 90$]$.

В 2012-2013 гг. музей в рамках сотрудничества с крупным арт-проектом уральского коллекционера и предпринимателя Александра Шадрина представил в своих залах ряд интересных выставок: «Шедевры Сальвадора Дали», «Великие классики XX века» Анри Матисс, Пабло Пикассо, Василий Кандинский, «От Шемякина до Пикассо», который также с огромным успехом был принят в республике.

В 2015 г. состоялся второй проект музея в рамках реализации указа Президента РФ - выставка из фондов Музея древнерусской культуры и искусства им. А. Рублева «Воинство небесное. Памятники XIII - начала XX века». За месяц работы выставку посетило более 5 тысяч человек.

В 2018 г. в Художественном музее им. Ц. С. Сампилова открылась мультимедийная выставка «Винсент Ван Гог. Ожившие полотна». Это было новое анимационное шоу-представление полотен великого нидерландского художникапостимпрессиониста. Выставка вызвала огромный интерес у жителей и гостей республики [3, с. 376-386].

При поддержке Правительства и Министерства культуры Республики Бурятия 3 апреля 2019 г. открылась первая в регионе интерактивная экспозиция «Таеж- 
ная, озерная, степная» Музея природы Бурятии в здании Художественного музея им. Ц. С. Сампилова. На экспозиции создана возможность использования цифровых технологий для расширения музейного пространства, учтены интересы всех психотипов посетителей: аудиалов, визуалов, кинестетиков и т. д. Предусмотрены «живые этикетки», тактильные макеты некоторых экспонатов, интерактивные экспонаты во всех разделах, звуковое сопровождение, игровые зоны, релаксзоны с удобными сиденьями и возможностью просмотра фильмов о природе Бурятии. В экспозиции большое значение уделено созданию аудиовизуального контента, его техническому оснащению - использование 3D-мепинга и анимированных графических образов, проецирующихся на макет озера Байкал, позволило «оживить» экспозицию. Тем самым еще раз акцентировать внимание посетителей на изучение озера Байкал как уникальной жемчужины мира. Всего экспозицию посетило не менее 36000 человек.

В 2020 г. в сложный год пандемии для жителей и гостей города Улан-Удэ Национальный музей Бурятии на площадке Художественного центра смог реализовать топовый проект - выставку «Новая степь» всемирно известного художника Зорикто Доржиева. Выставка художника была дополнена мультимедийным проектом, подготовленным галереей «Ханхалаев» в коллаборации с молодым видеографом Арюна Song. Это своеобразные видеоклипы по произведениям художника в музыкальном сопровождении певицы Урны.

В 2020 г. музей при поддержке Министерства культуры Республики Бурятия сделал высокоточную страховую копию мирового шедевра — «Атласа тибетской медицины», что позволило организовывать передвижные выставочные проекты для представления памятника на музейных площадках не только России, но и зарубежья. В июне 2021 г. страховая копия «Атласа тибетской медицины» впервые была представлена на передвижной выставке в Национальном музее Республики Тыва им. Алдан-Маадыр.

В последние годы в мире также рассматривается понятие «экономика впечатлений», которое применяется для туристической отрасли. Впечатления имеют важное значение в сфере сервиса и являются необходимым элементом маркетинга, которое способствует созданию привлекательного бренда территории [6].

«Экономика впечатлений» также повлияла на музейный маркетинг. На протяжении многих лет музей работает над улучшением качества сервисных услуг, были разработаны внутренние стандарты обслуживания, введен зимний и летний режим работы, установлены переносные подъемники и пандусы для маломобильных граждан и т. д.

Национальный музей Бурятии ежегодно организует крупные международные и межрегиональные проекты, участвует в конференциях, семинарах, туристических форумах, фестивалях, где с достоинством представляет культурное наследие, выдающиеся достижения и наиболее яркие, привлекательные и преимущественные стороны республики: многообразие природных ландшафтов Бурятии, озеро Байкал, религиозные традиции, символы буддизма, многовековую дружбу народов Бурятии.

Таким образом, сегодня Национальный музей Республики Бурятия играет большую роль в развитии региональной креативной экономики и, сохраняя уни- 
T. А. Бороноева. Национальный музей Республики Бурятия как ресурс региональной креативной экономики

кальное культурное наследие, становится прямым ресурсом дальнейшего экономического успеха.

Литература

1. Альжанова Ф., Днишев Ф. Креативная экономика: синергия культуры, бизнеса и технологий (мировая практика и Казахстан). Вена, Австрия: Ассоциация перспективных исследований и высшего образования «Восток - Запад». 2015. 276 с. Текст: непосредственный.

2. Бороноева Т. А. Социокультурная миссия Художественного музея им. Ц. С. Сампилова в составе Национального музея Республики Бурятия // Изобразительное искусство Урала, Сибири, Дальнего Востока. 2021. № 1(6). С. 7-13. Текст: непосредственный.

3. Бороноева Т. А., Бальжурова А. Ж. Международные и межрегиональные выставочные проекты национального музея Республики Бурятия как опыт интеграции // Культурное пространство России и Монголии: опыт и перспективы сотрудничества в трансграничных регионах: материалы VIII Международной научно-практической конференции / ответственный редактор Е. Ю. Перова. 2019. С. 376-386. Текст: непосредственный.

4. Бороноева Т. А., Гомбоев Б. Ц. Роль Национального музея Республики Бурятия в развитии музейного дела и туристической отрасли // Современные проблемы сервиса и туризма. 2018. № 12(1). С. 88-102. Текст: непосредственный.

5. Международный год креативной экономики в целях устойчивого развития // http://ru.unesco.kz/international-year-of-creative-economy-for-sustainable-development (дата обращения: 28.06.2021 г.). Текст: электронный.

6. Музеи в контексте экономики впечатлений. URL: https://studme.org/76756/turizm/muzei_kontekste_ekonomiki_vpechatleniy (дата обращения: 30.06.2021 г.). Текст: электронный.

7. Минкультуры представило на обсуждение проект по развитию креативных индустрий. URL: https://rg.ru/2021/06/11/minkultury-predstavilo-na-obsuzhdenie-proekt-porazvitiiu-kreativnyh-industrij.html (дата обращения: 30.06.2021г.). Текст: электронный.

8. Культура как отрасль креативной экономики. URL: https://studme.org/330483/ekonomika/kultura_otrasl_kreativnoy_ekonomiki (дата обращения: 29.062021 г.). Текст: электронный.

9. Перелыгина В. В. Трансформация музейного продукта как направление совершенствования организации обслуживания посетителей: выпускная квалификационная работа. Белгород, 2019. С. 28. 43.04.01 Сервис. Организация и управление коммерческой деятельностью. URL: http://dspace.bsu.edu.ru/handle/123456789/42757 (дата обращения: 29.06 2021 г.). Текст: электронный.

10. Российские музеи как ресурс креативной экономики в XXI в. URL: https://artandyou.ru/articles/rosssiskie_muzei_kak_resurs_kreativnoi_ekonomiki/ (дата обращения: 28.06.2021 г.). Текст: электронный.

11. Скрипкина Л. И. Роль музеев в формировании региональной социокультурной политики // Учёные записки (АГАКИ). 2017. № 4(14). URL: https://cyberleninka.ru/article/n/ rol-muzeev-v-formirovanii-regionalnoy-sotsiokulturnoy-politiki (дата обращения: 14.07.2021). Текст: электронный.

Статья поступила в редакциию 13.07.2021; одобрена после рецензирования 30.07.2021; принята к публикации 18.08.2021 


\section{NATIONAL MUSEUM OF THE REPUBLIC OF BURYATIA AS A RESOURCE OF THE REGIONAL CREATIVE INDUSTRY}

\section{Tatyana A. Boronoeva}

Cand. Sci. (Art History)

Honored Art Worker, Honorable Academician of the Russian Academy of Arts, Director of National Museum of the Republic of Buryatia

29 Kuibysheva St., Ulan-Ude 670000, Russia tatboronoeva@gmail.com

Abstract. The article analyzes the role of the National Museum of the Republic of Buryatia in the development of the regional creative industry. The museum preserves a unique cultural heritage, which is considered as one of the main resources of the creative industry. Over the past ten years, the museum has been actively developing a brand name, publications and souvenir products, promoting its own line of museum products created on the basis of the richest collections, organizing a sales infrastructure (a sales exhibit "Art-Belig" has been opened in the Art Museum). We also considered the museum's activity within the framework of the concept of "the economy of impressions" as a significant participant in branding of the territory, expansion of cultural tourism and creative industries. Thus, the article emphasizes that the National Museum of the Republic of Buryatia is an integral part of the regional cultural industries.

Keywords: museum, creative industry, resource, culture, heritage, museum product, tourism, collection, exhibition

\section{For citation}

Boronoeva T. A. National Museum of the Republic of Buryatia as a Resource of the Regional Creative Industry. Bulletin of Buryat State University. Economy and Management. 2021; 3: 19-26 (In Russ.).

The article was submitted 13.07.2021; approved after reviewing 30.07.2021; accepted for publication 18.08.2021. 